\title{
Bleaching Process on Oil Palm Empty Bunches by Pulping Using Formacell Liquid Waste
}

\author{
SRI HIDAYATI ${ }^{1 *}$, RIBUT SUGIHARTO ${ }^{1}$, SUTOPO HADI ${ }^{2}$ \\ ${ }^{1}$ Department of Agricultural Product Technology, Faculty of Agriculture, Universitas Lampung Bandar Lampung 35145, Indonesia \\ ${ }^{2}$ Department of Chemistry, Universitas Lampung, Bandar Lampung 35145, Indonesia
}

\begin{abstract}
The formacell process produces black liquor that damages the environment. Previous research has shown that black liquor can be used as a cooking solution for pulping. The pulping process using formacell waste on oil palm empty bunches produces a dark color; therefore, it requires a bleaching process. The aim of this study was to determine the effect of the type of cooking solution (fresh pulping solution and leachate residual from pulping) and bleaching time (0.5, 1, 1.5, 2, and $2.5 \mathrm{~h})$ on pulp yield, cellulose content, permanganate number, and score on whiteness degree. The bleaching process used $35 \%$ peracetic acid and was conducted at $80^{\circ} \mathrm{C}$. The best results were obtained at a bleaching time of 2 $h$, which resulted in yields of $76.1 \%-81.2 \%$, cellulose contents of 53\%-62.5\%, permanganate numbers of 6.3-7.4, and scores of color of 3.78 (yellowish white) to 4.7 (white).
\end{abstract}

Keywords: bleaching, oil palm empty bunches, formacell, peracetic acid

\section{Introduction}

One of the problems in the pulp and paper industry is the presence of leachate known as black liquor, which pollutes the environment and has low recycling ability [1]. Simkhovich et al. reported that one of the advantages of using organic acid as a cooking solution for pulping was that liquid waste could be reused for pulp cooking [2]. The main objective of the recycling process is to reduce the impact of pollution on the environment [3]. In the process of cooking (pulping), lignin cannot be completely separated. Moreover, a high content of lignin in pulp produces low-quality paper that is rigid, easily broken, and dark in color.

To obtain whiter and non-degradable pulp, bleaching is a necessary process in pulping. However, an improper bleaching process results in reduced strength of the paper because of side reactions caused by the degradation of fibers [4]. To reduce or alleviate this degradation, it is necessary to select effective, appropriate, inexpensive, and efficient chemicals to improve the physical properties of the pulp produced. Chlorine has been widely used for bleaching; however, its use is limited because it pollutes the environment and is toxic [5].

One of the environmentally friendly oxidizers that can be used as a bleaching agent is peroxide acid, which includes organic peroxide [6,7]. Peroxide acid dissolved in acetic acid, known as peracetic acid, is an environmentally friendly bleach, has great potential as a non-chlorine bleach [8] and is selective and effective for delignification [9,10,11]. Many studies have been reported to show the ability of peracetic acid to bleach the pulp $[12,13]$. Thus, the use of peracetic acid will reduce the use of chlorine which is harmful to the environment $[6,14]$.

The ability of peroxide acid to delignifying pulp is due to the presence of the hydroperoxide anion, which decomposes into hydroxyl and superoxide anions. However, such a process requires control in the bleaching process because if hydroperoxide anion is excessive, this anion can also attack cellulose and decrease the pulp strength [15]. Poppius-Levlin et al. [16] stated that the advantage of peracetic acid over oxygen-based chemicals was that peracetic acid reacted selectively with lignin and left the pulp carbohydrates practically intact. Barros et al. [17] reported that peracetic acid was relatively fast when applied at the last stage of elemental chlorine free (ECF) bleaching sequences. A reaction time of 120 min at $75^{\circ} \mathrm{C}$ and $p \mathrm{H} 5.0$ was seemingly adequate, regardless of the peracetic acid dose, in the range of $1-5 \mathrm{~kg} / \mathrm{ton}$ pulp and bleaching sequence.

*email: srihidayati.unila@gmail.com 
Some important factors that influence the results of pulp bleaching are the concentration of bleach [18], the duration of the bleaching process [17], temperature, $p \mathrm{H}$, and the ratio of bleaching materials to pulp $[18,19]$. The purpose of this study was to determine the effect of bleaching time on the characteristics of OPEB pulp produced from the pulping process using formacell cooking waste.

\section{Materials and methods}

\subsection{Materials and instrumentation}

The materials used were OPEBs obtained from the PT Rejosari Palm Mill Lampung, Indonesia. All reagents were $\mathrm{AR}$ grade. $\mathrm{KMnO}_{4}, \mathrm{KI}, \mathrm{Na}_{2} \mathrm{~S}_{2} \mathrm{O}_{3}, \mathrm{HCl}$, glacial acetic acid, $\mathrm{H}_{2} \mathrm{SO}_{4}$, and starch indicatorwere obtained from Merck and were used as received. The equipment consisted of a pulp cooking digester, a permanganate number determinant and an oven. The IR spectra were recorded using a Fourier transform infrared (FTIR) Agilent 670 series with $\mathrm{KBr}$ discs in the range of $4000-400 \mathrm{~cm}^{-1}$.Scanning electron microscope (SEM) was obtained with JEOL JSM 6510LA.

\subsection{Research procedures}

The pulping process was carried out by cleaning the OPEBs that had been fibrillated or decomposed; $1000 \mathrm{~g}$ was weighed and placed in an Erlenmeyer reactor with a condenser, and then filled with a cooking solution of $32.74 \%$ formic acid in glacial acetic acid. The ratio of cooking solution to OPEB was 15:1 $(\mathrm{v} / \mathrm{w})$. The mixture was macerated for $1 \mathrm{~h}$, followed by cooking at $130^{\circ} \mathrm{C}$ for $1.71 \mathrm{~h}$.

After cooking, filtering was performed to obtain both pulp and filtrate (Cycle 1). The pulp was washed and dried, whereas the filtrate, in the form of black liquor (leachate), was reused for cooking OPEBs by the same procedure, followed by filtration (Cycle 2), washing, and drying of the pulp with oven at $50^{\circ} \mathrm{C}$ until the water content was constant, then the morphology was monitored with SEM and FTIR to see the functional groups.

Dried pulps from both the cycles were then bleached using peracetic acid in acetic acid (Table 1). The bleaching process was conducted at $80-84^{\circ} \mathrm{C}$ with time variations of $0.5,1,1.5,2$, and $2.5 \mathrm{~h}$ by placing $100 \mathrm{~g}$ of dried pulps in Erlenmeyer containing $1 \mathrm{~L}$ peracetic acid. The pulp was then filtered off, washed and dried. All treatments were carried out in triplicate.

The dried pulps were then tested on the cellulose content [20], permanganate number [21], pulp yields, and whiteness scores based on the scoring test, and the characterization of functional group using FTIR. The morphology of fibers was analyzed using scanning electron microscopy (SEM) and was carried out on OPEB fiber before cooking, before and after bleaching process.

Table 1. Typical peracetic acid pulp bleaching conditions

\begin{tabular}{|l|c|c|}
\hline Chemical dosage & Hydrogen peroxide (30\%), mL & 35 \\
\hline Reaction temperature ( $\left.{ }^{\circ} \mathrm{C}\right)$ & Acetic Acid $(95 \%), \mathrm{mL}$ & 65 \\
\hline Reaction time (hour) & & $80-84$ \\
\hline Pulp consistency (\%) & $0.5 \sim 2.5$ \\
\hline
\end{tabular}

\section{Results and discussions}

\subsection{Pulp Yield}

Increasing the bleaching time reduced the yield of OPEB pulp processed using formacell wastewater (Figure 1). The pulp yields resulting from the experiment were in the range of $70.0 \%-81.2 \%$.The process in Cycle 1increased the pulp yield at all the bleaching times, whereas the process in Cycle 2 decreased 
the yield at a bleaching time of $1.5 \mathrm{~h}$. Peracetic acid is an environmentally friendly bleach [22]. Itis an oxidizing agent that, during the bleaching process, can degrade and hydrolyze cellulose into fragments that dissolve in water, causing a decrease in pulp yield [23]. The highest pulp yield of OPEBs produced from $0.5 \mathrm{~h}$ of bleaching time was $81.2 \%$, whereas Zhao et al. [24] reported that the highest pulp yield of bagasse occurred at a bleaching time of $2.5 \mathrm{~h}(58.1 \%)$. In this study, the pulp yield of OPEBs produced at a bleaching time of $2.5 \mathrm{~h}$ was $78.1 \%$.

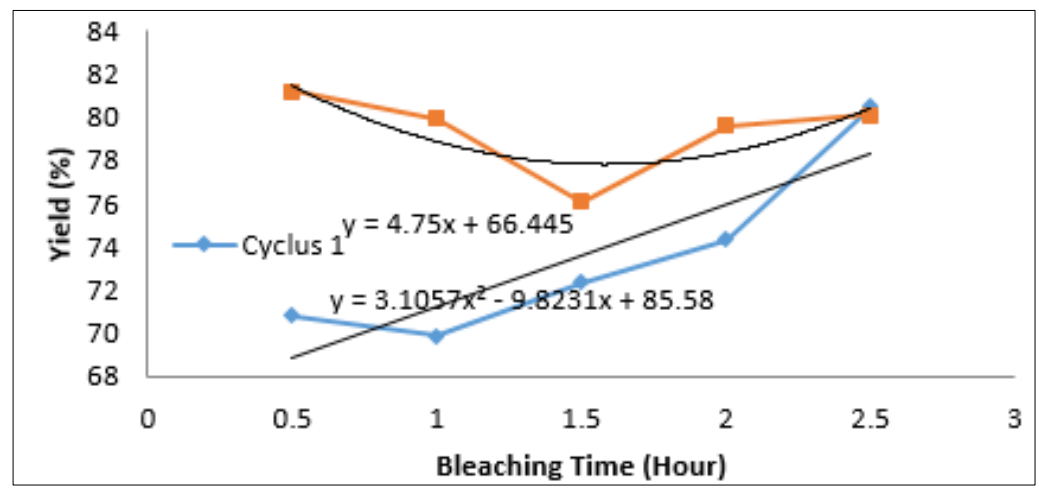

Figure 1. Effect of bleaching time on yield of OPEB pulp resulting from the process of cooking cycles 1 and 2

\subsection{Cellulose content}

The results showed that an increase in bleaching time reduced the cellulose content of pulp bleached from both Cycle 1 and Cycle 2 (Figure 2). The cellulose contents produced ranged from 44 to $62.5 \%$.

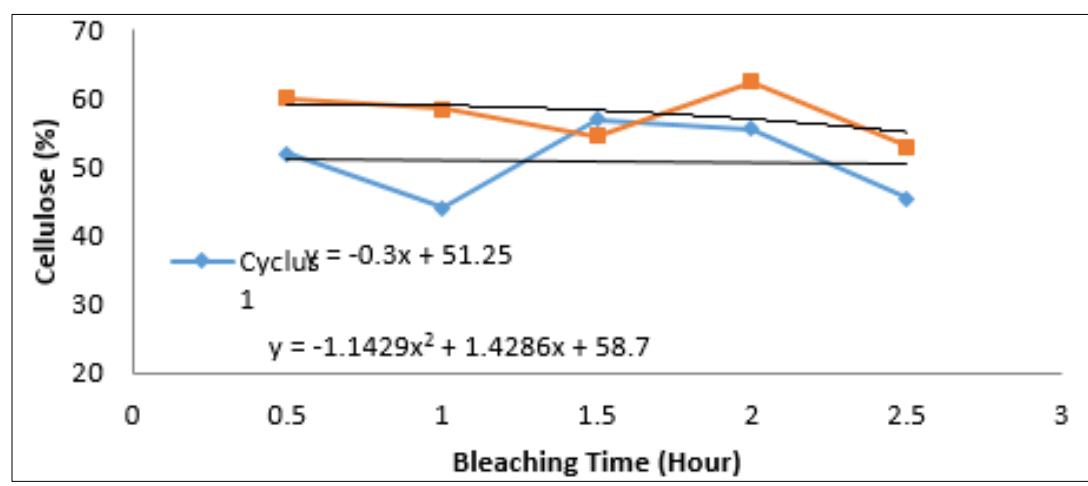

Figure 2. Effect of bleaching time on cellulose content of OPEB pulp resulted from cycle 1 and cycle 2 cooking

In Cycle 1 there was an increase in cellulose content at $1.5 \mathrm{~h}$ of bleaching, whereas in Cycle 2 the cellulose content decreased. Peroxide acid was a bleaching medium that was quite selective even though it was oxidative; however, it decomposed cellulose in only small amounts [25], and the results of decomposition were simple sugars easily soluble in water. The length of bleaching time can cause active peroxide to break down cellulose even more, resulting in a decrease in cellulose levels. Zhao et al. [24] showed that peracetic acid was a selective medium and did not cause high cellulose damage. The cellulose content produced from bleaching for $2.5 \mathrm{~h}$ using $15 \%$ peracetic acid was $78.5 \%$. Increasing the bleaching time in flax fiber using peracetic acid did not cause fiber damage; therefore, peracetate was suitable for flax fiber bleaching [26].

\subsection{Permanganate number}

The results showed that the increase in bleaching time caused the permanganate number to decrease (Figure 3). The value of the permanganate number ranged from 6.3 to 7.4. Permanganate number or 
kappa number is the amount of permanganate consumption in a pulp sample containing lignin that has not reacted. This number can be used to determine the level of lignin in pulp. According to the National Standardization Board [21], the analysis of permanganate numbers can be used to determine the level of maturity or whiteness of a pulp. Peracetic acid is an oxidizer; hence, it can oxidize the lignin contained in pulp. Additionally, the opening of the aromatic ring makes oxidized lignin more hydrophilic, and it dissolves in the bleach solvent. Acid group formation also supports the solubilization of lignin fragments, especially during the alkali extraction stage, due to ionization [17]. The removal of lignin by peracetic acid could occur via two reactions, (1) peracetic acid reduces themolecular weight of lignin by cleaving, carbon-oxygen, carbon-carbon and $\beta$ aryl ether bonds; (2) dealkylation of O-methyl groups, addition of hydroxyl groups and cleavage of aromatics rings in lignin polymer; these reactions increase the polarity of lignin and remove the lignin easily [27]. In Cycles 1 and 2 of cooking, there was a decrease in permanganate number at various bleaching times. Increasing the length of bleaching time caused the penetration of the bleaching agent or the ability to oxidize peracetic acid to lignin, which increased lignin content and increased white power. This was demonstrated by the decreasing value of the permanganate number. The lignin content in pulp was lower with lower kappa numbers and permanganate numbers.

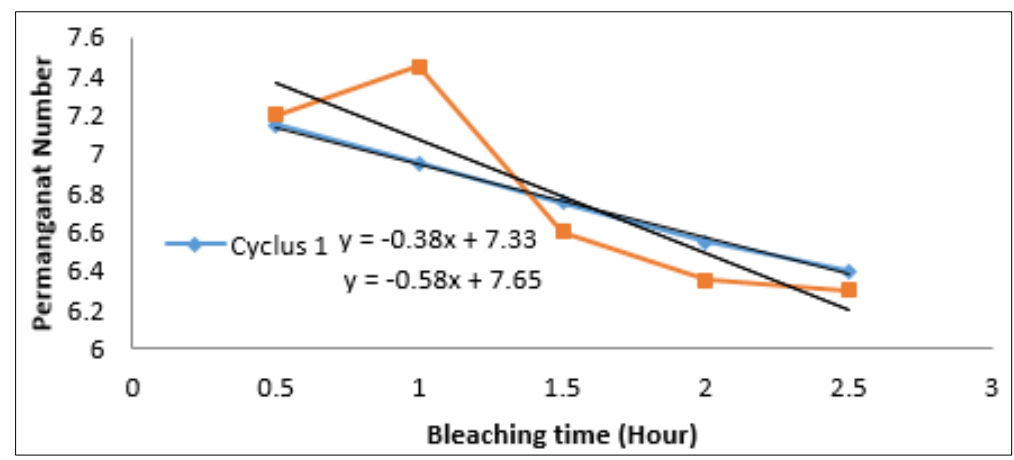

Figure 3. Effect of bleaching time on permanganate number of OPEB pulp resulted from cycle 1 and cycle 2 cooking

\subsection{Score on whiteness color}

Increasing the bleaching time increased the whiteness grade score (Figure 4). The scores ranged from 1 (brown), 2 (yellowish brown), 3 (yellow), 4 (yellowish white), and 5 (white). The highest color occurred at a bleaching time of $1.5 \mathrm{~h}$, which was 4.5 (white). Cycles 1 and 2 of cooking had the same tendency: an increase in the whiteness scoreuntil a bleaching time of $1.5 \mathrm{~h}$ and then a decrease in the whiteness score. The results showed that the use of peracetic acid was able to reduce the color from yellow to white. The improvement in whiteness was sustained for the production of high brightness paper (+96\% of ISO) [28].

An increased bleaching time could increase the brightness of the pulp. This was presumably because the longer the bleaching time, the more perfectly the lignin oxidation process, especially in oxidizing the chromophore. This results in a great deal of lignin being released, marked by a decrease in the permanganate number. The longer bleaching time made the $\mathrm{H}_{2} \mathrm{O}_{2}$ solution more reactive. The bleached reaction species of alkaline hydrogen peroxide are hydroperoxy anions $\mathrm{HOO}^{-}$. The decomposition intermediates, such as hydroxyl $\mathrm{HO} \bullet$ and superoxide anion $\mathrm{O}_{2}-\bullet$ radicals, have generally undesirable influence in bleaching processes [16]. The mechanism process involves the hydrogen peroxide-oxidized non-phenolic units of lignin through the release of one electron and forms a cation radical that then decomposes chemically. Lignin consists of $90 \%$ non-phenolic units. The phenol lignin unit can be oxidized by alkali into a light-absorbing structure, resulting in lower optical properties [29]. Peracetic acid can react as electrophiles and also nucleophiles [30]. As an electrophile, it attacks the phenolic and non-phenolic lignin structures while the nucleophilic secondary reaction focuses on the carbonyl structure. The open aromatic rings will make oxidized lignin more hydrophilic, contributing to its its 
solubilization in the bleaching liquor [31] Patel et al. [26] reported that bleaching times of 1 and $2 \mathrm{~h}$ in jute using peracetate had no significant effect on whiteness degree.

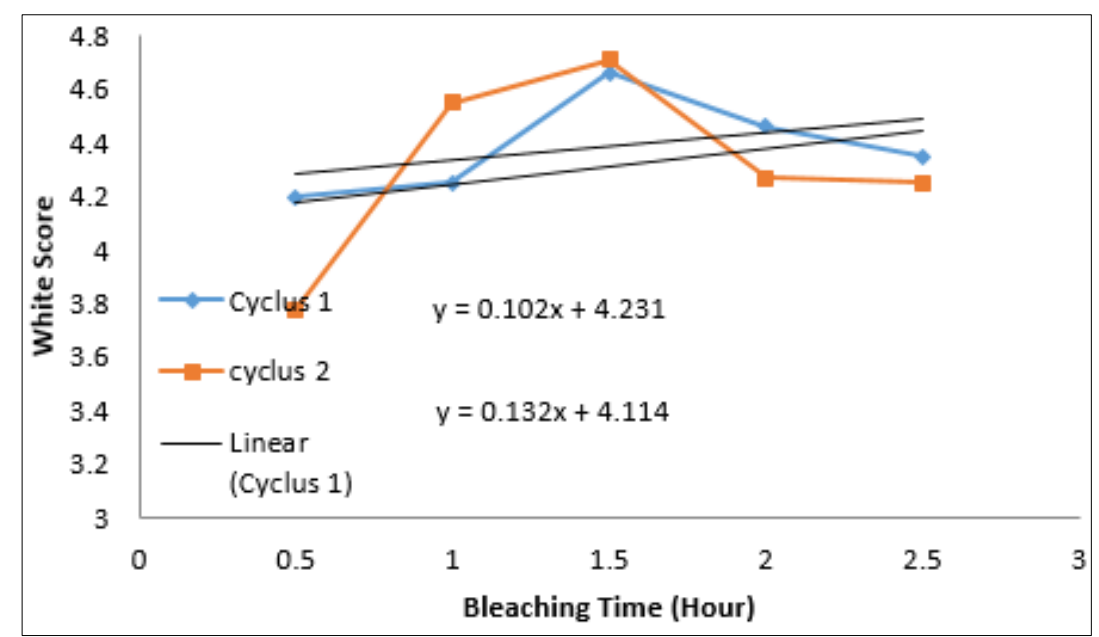

\subsection{FTIR spectra}

Figure 4. Effect of bleaching time on whiteness score of OPEB pulp resulted from cycle 1 and cycle 2 cooking

Infrared spectroscopy was used to determine the constituent structure and changes of lignocellulose during the bleaching process. The FTIR spectra of unbleached pulp and bleached pulp using peracetic acid are shown in Figures 5 (Cycle 1) and 6 (Cycle 2).

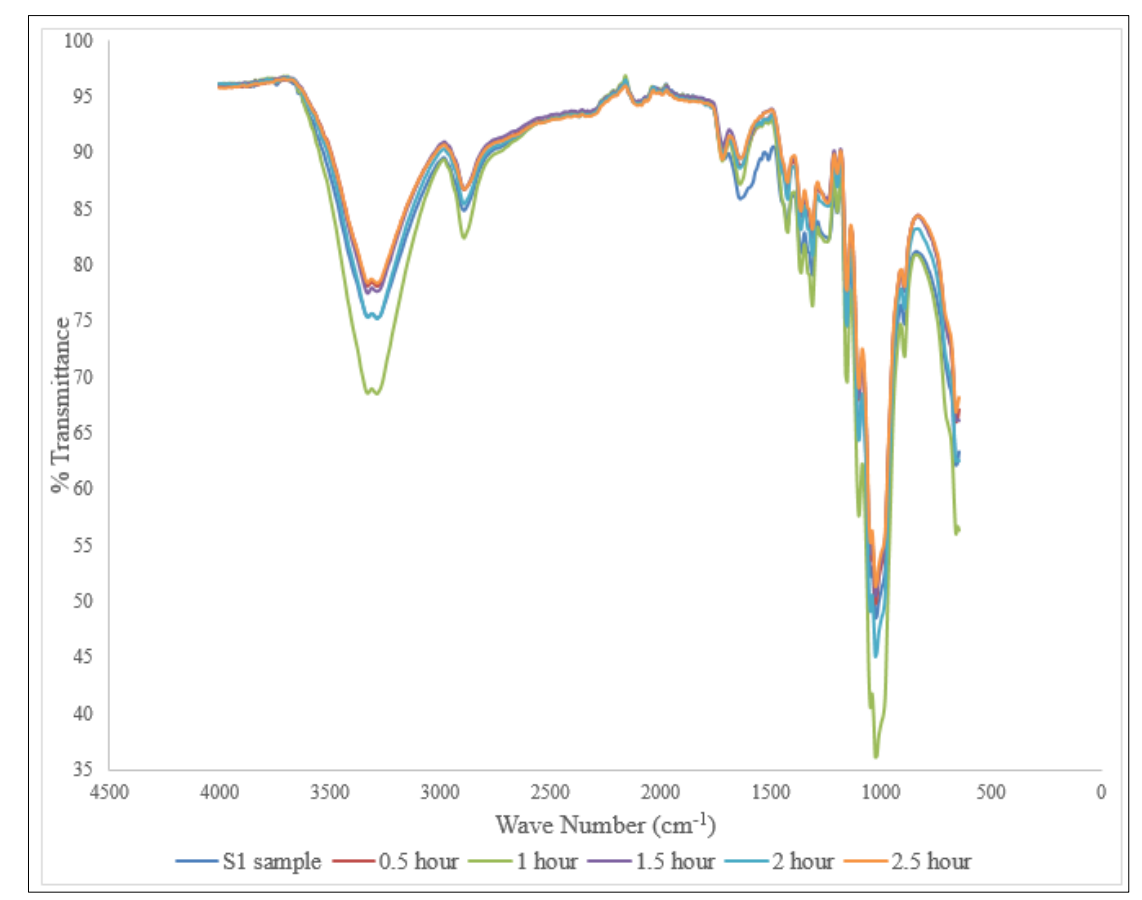

Figure 5. FTIR spectrum obtained from the effect of bleaching time on OPEB pulp from cycle 1 cooking

The spectra demonstrated that there was a similar pattern between the results of bleaching in Cycles 1 and 2. There was an increase in cellulose levels in all bleached pulp compared with unbleached OPEB pulp. The wave numbers at 1430,1375, 1155, 1108, 1030, and $895 \mathrm{~cm}^{-1}$ showed the presence of asymmetric $\mathrm{CH}$, symmetric $\mathrm{CH}$, asymmetric viability $\mathrm{COC}$, glucose ring stretching, $\mathrm{CO}$ stretching, and stretching of COC $\beta$-glycosidic bonds or glucose, respectively, which are characteristic of cellulose [32, 33]. The visible band of bleached pulp was more intensive than that of unbleached pulp. Lignin was seen 
in wave numbers between 1600 and 1510. Lignin was more clearly seen in unbleached pulp than in bleached pulp for both Cycle 1 and Cycle 2 of cooking. Additionally, lignin from Cycle 2 of cooking was stronger than that from Cycle 1 of cooking, because the lignin build up from Cycle 2 of cooking was obtained from formacell liquid waste.

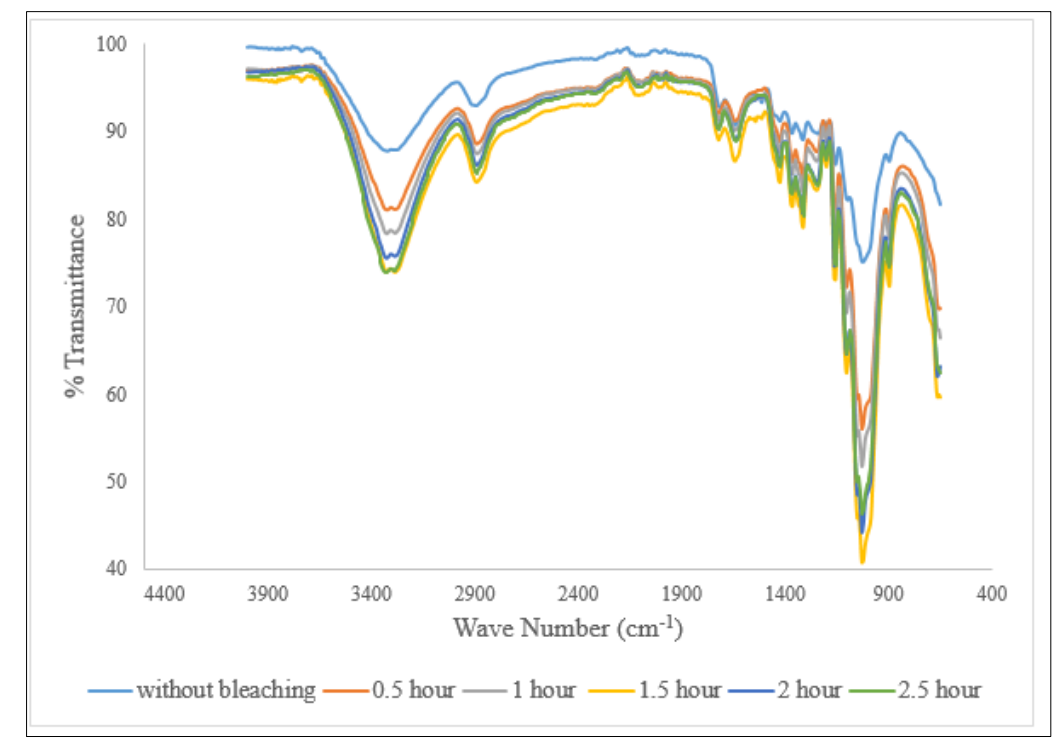

Figure 6. FTIR spectrum obtained from the effect of bleaching time on OPEB pulp from cycle 2 cooking

\subsection{Assessment of the Structure of the Pulp Fibers Using SEM}

SEM was used to determine the change in fiber structure in OPEB pulp. The magnification was 500x. The surface of OPEB fiber is uneven, and consists of bundles with individual cells that are constantly bound together by the components of lignin and hemicellulose and the presence of a circle that shows the presence of silica. White granules are silica objects known as phytoliths, and they are embedded in the surface of OPEB fibers [34, 35]. OPEB SEM fibers have long vascular and large-diameter fibers [36]. Changes in fiber structure with the disappearance of silica and fiber structures that were originally crystalline or rigid become irregular [37]. Figure 7 shows that bleached OPEB pulp for $2.5 \mathrm{~h}$ produced brighter fibers than bleached pulp for only $0.5 \mathrm{~h}$ or nonbleached pulp with a more amorphous and irregular fiber structure with loss of lignin.
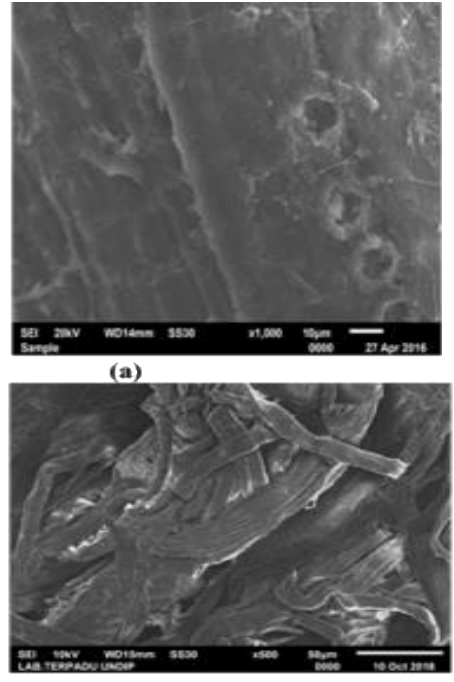

(b)
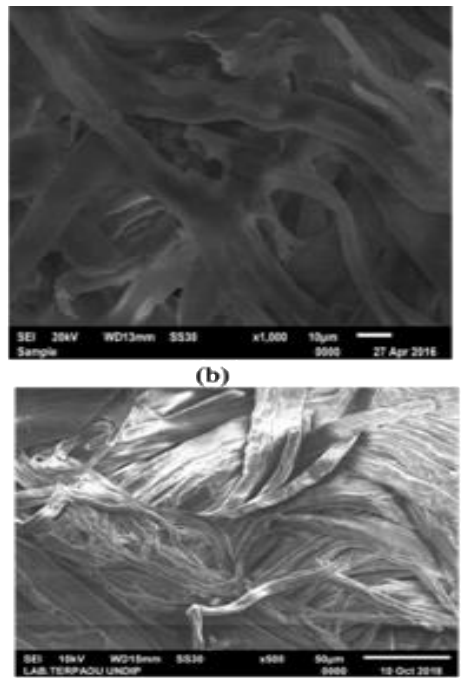

(d)
Figure 7.SEM pictures resulted from (a) OPEB fibers (b) OPEB pulp of formacell process without bleaching, (c) OPEB pulp of formacell process, bleached for $0.5 \mathrm{~h}$ using peroxide acid in acetic acid media, and (d) OPEB pulp of formacell process, bleached for $2.5 \mathrm{~h}$ using peroxide acid in acetic acid media 


\section{Conclusions}

The results showed that the increase in bleaching time reduced the yield, cellulose content, and permanganate number of pulp produced from Cycles 1 and 2 of cooking. The best results were obtained from Cycle 2 of cooking at a bleaching time of $2 \mathrm{~h}$, which produced a pulp yield of $79.6 \%$, a cellulose content of $62.5 \%$, a permanganate number of 6.35 , and a score of whiteness color of 4.27 (yellowish white).

Acknowledgment: The authors would like to thank to The Dean of Faculty of Agriculture, Universitas Lampung for the funding support given in the process of publication. Special thank goes to www.enago.com that helps us in reviewing and proofreading.

\section{References}

1.JAHAN, M.S., LEE, Z.Z., JIN, Y., Organic Acid Pulping of Rice Straw. I: Cooking, Turk. J. Agric. For.,30(3), 2006,231-239.

2.SIMKHOVICH, B.S., ZILBERGLEIT, M.A., REZNIKO, V.M., Papermaking properties of acetic acid pulp from hardwoods, Bum. Prom., 7, 1987, 25-26.

3. DULDNER, M.M., BARTHA, E., CAPITANU, S., NICA, S., COMAN, A.E., TINCU, R., SARBU, A., FILIP, P.I., APOSTOL, S., GAREA, S., Rev. Chim., 70 (7), 2019, 2301-2307

4. CASEY, J.P., Pulp and Paper: Chemistry dan Chemical Technology VI: Pulping and Bleaching, $2^{\text {nd }}$ edition, New York, 1980, p. 396.

5. GONCALVES, A.R., DENISE, D., MORIYA, R., OLIVERIA, L.R.M., Pulping of sugarcane bagasse straw biobleaching of the pulps: conditions parameters dan recycling of enzymes.59 ${ }^{\text {th }}$ Appita Annual Conference and Exhibition: Incorporating the $13^{\text {th }}$ ISWFPC (International Symposium on Wood, Fibre and Pulping Chemistry), Auckland, New Zealand, 2005, pp. 597-602.

6. SHARMA, N., BHARDWAJ, N. K., PRASHAD SINGH, R.B., Environmental issues of pulp bleaching and prospects of peracetic acid pulp bleaching: A Review, J. Clean. Prod., 256, 2020, 120338.

7. BALAN, G.G., PAVEL, L., SANDU, A.V., STEFANESCU1, G., TRIFAN, A.V., Preliminary Study on Erosion of Polymer Coatings of Duodenoscopes, Mater. Plast., 53(4), 2016, 791-795.

8. RICKETTS, J.D., Role of peracids revisited for delignification, bleaching., Pulp Paper,69(3), 1995, 89-94.

9. SPRINGER, E.L., Delignification of wood and kraft pulp with peroxymono- phosphoric acid.J. Pulp Paper Sci.,23(12), 1997, 582-584.

10. ABOU-YOUSEF, H., Bagasse pulping by using Caro's acid, J. Korea Tech. Assoc. Pulp Paper Ind., 33(5), 2001, 30-36.

11. ZHAO, X., ZHANG, T., ZHOU, Y., LIU, D., Preparation of peracetic acid from hydrogen peroxide - Part 1: Kinetics for peracetic acid synthesis and hydrolysis, J. Mol. Catal. A: Chem., 271(1-2), 2007, 246-252.

12.SUN, R., TOMKINSON, J., ZHU, W., WANG, S.Q., Delignification of maize stems by peroxymonosulfuric acid, peroxyformic acid, peracetic acid, and hydrogen peroxide. 1. Physicochemical and structural characterization of the solubilized lignins, J. Agric. Food Chem., 48(4), 2000, 1253-1262.

13.LEE, H.R., KAZLAUSKAS, R.J., PARK, T.H., Mild pretreatment of yellow poplar biomass using sequential dilute acid and enzymatically-generated peracetic acid to enhance cellulase accessibility, Biotechnol. Bioprocess Eng., 22, 2017, 405-412.

14.POPESCU, E.M., PANTEA, O., GOLOGAN, D., DOUKEH, R., Hydrogen Peroxide and Peracetic Acid Oxidizing Potential in the Treatment of Water, Rev. Chim., 70(6), 2019, 2036-2039.

15.POTUCEK, F., MILICHOVSKY, M., Kraft pulp bleaching with hydrogen peroxide and peracetic acid, Chem. Paper, 54(6a), 2010, 406-411. 
16. POPPIUS-LEVLIN, K., JÄÄSKELÄINEN, A.S., SEISTO, A., FUHRMANN, A., Peracids in Kraft Pulp Bleaching: Past, Present, and Future., ACS Symp. Series, 742(42), 1999, 471-489.

17.BARROS, D.P., SIVA, V.L., HAMALAMAN, H., COLODETTE, J.L., Effect of lasst stage bleaching with peracetic acid on brightness development and properties on eucalyptus pulp. BioResources, 5(2), 2010, 881-898.

18.VAN DAAM, J.E.G., Coir Processing Technologies: Improvement of Drying, Softening, Bleaching and Dyeing Coir Fibre/Yarn and Printing Coir Floor Coverings, FAO and CFC, Netherlands, 2002.

19.TUTUS, A., Bleaching of Rice Straw Pulps with Hydrogen Peroxide, Pak. J. Biol. Sci., 7(8), 2004, 1327-1329.

20DATTA, R., Acidogenic fermentation of lignocellulose acid yield and conversion of components, Biotechnol. Bioeng., 23, 1981, 2167-2170.

21. INDONESIAN STANDARDIZATION BOARD (Dewan Standardisasi Indonesia), SNI 0494-1989A. Cara Uji Bilangan Permanganat, Bilangan Kappa, dan Bilangan Khlor Pulp, Departemen Perindustrian. Jakarta, 1989. (in Indonesian)

22.PANDEY, S., CHATTOPADHYAY, S.,PAN, N., Recent developments in bleaching of jute and allied fibres, Colourage, 40(10), 1993, 29-34.

23.DENCE, C.W AND. REEVE, D.W., Pulp Bleaching, Principle and Practice, TAPPI Press, Atlanta, Georgia, 1996, p. 396.

24.ZHAO, X., VAN DERR HERDE, E., ZHANG, T., LIYU, D., Delignification of sugarcane bagasse with alkali acid peracetic acid and characterization of the pulp, BioResources, 5(3), 2010, 1565-1580.

25.NADA, A.A.M.A., IBRAHEM, A.A., FAHMY, Y., ABOU-YOUSEF, H.E., Peroxyacetic acid pulping of bagasse and characterization of the lignin and pulp, J. Sci. Ind. Res. India, 58(8), 1999,620628.

26.PATEL, S., SHARAN, M, CHATTOPADHYAY, D.P., Studies on peracetic acid bleaching and dyeing of jute with turmeric, Int. J. Innov. Res. Multidisc. Field, 3(5), 2017, 132-136.

27.JAHAN, M.S., HOSEN, M.M., RAHMAN, M.M., Comparative study on the prebleaching of bamboo and hardwood pulps produced in Kharnaphuli Paper Mills, Turk. J. Agric. For., 37, 2013, 812-817

28.TRIPATHI, S., MISHRA, S.P., MISHRA, O.P., BAJPAI, P., KUMAR, S., BAJPAI, P.K., Application of peracetic acid in chemical pulp bleaching, J. Ind. Pulp Paper Tech. Assoc., 19(1), 2007, 76- 82.

29.LI, Z., COURT, G. D., BELlivEAU, R., CROWELL, M., MURPHY, R., GIBSON, A., WAJER, M., BRANCH, B., NI, Y., Using magnesium hydroxide $\mathrm{Mg}(\mathrm{OH})_{2}$ as the alkali source in peroxide bleaching at Irving Paper, Pulp and Paper Canada, 106(6), 2005, 24-28.

30.PUITEL, A.C., BORDEIANU, A., GAVRILESCU, D., On Lignin Reactions In Tcf Kraft Pulp Bleaching, Cell. Chem. Technol., 41(4-6), 2007, 219-234.

31. BRASILEIRO, L.B., COLODETTE, J., PILO-VELOSO, D., DE OLIVEIRA, R.C., Bleaching of eucalypt kraft pulp with peracids: the effect on pulp characteristics, APPITA J., 55(6), 2002, 461-467

32NIKONENKO, N.A., BUSLOV, D.K., SUSHKO, N.I., ZHBANKOV, R.G., Investigation of stretching vibrations of glycosidic linkages in disaccharides and polysaccharides with use of IR spectra deconvolution, Biopolymers, 57(4), 2000, 257-62

33.YANG, Z. P., XU, S.W., MA, X. L., WANG, S.Y., Characterization and acetylation behavior of bamboo pulp, Wood Sci. Tech., 42(8), 2008, 621-632.

34.BAHARUDDIN, A.S., SULAIMAN, A., KIM, D.H., MOKHTAR, M.N., HASSAN, M.A., WAKISAKA, M., SHIRAI, Y., NISHIDA, H., Selective component degradation of oil palm empty fruit bunches (OPEFB) using high-pressure steam, Biomass \& Bioenergy, 55, 2013, 268-275.

35.FATAH ,Y.A., ABDUL KHALIL, H.P.S., HOSSAIN, M.S., AZIZ, A.A., DAVOUDPOUR, Y., DUNGANI, R., BHAT, A., Exploration of a chemo-mechanical technique for the isolation of nanofibrillated cellulosic fiber from oil palm empty fruit bunch as a reinforcing agent in composites materials, Polymers, 6(10), 2014, 2611-2624. 
36. LAW, K.N., DAVID, W.R.W., GHAZALI, A., Morphological and chemicalnature of fiber strands of Oil Palm Empty-Fruit-Bunch (OPEFB), BioResources, 2(3), 2007, 351-362.

37.HIDAYATI, S., ZUIDAR A.S., SATYAJAYA, W., Effect of acetic acid: formic acid ratio on characteristics of pulp from Oil Palm Empty Fruit Bunches (OPEFB). ARPN J. Eng. Appl. Sci.,12(12), 2017, 3802-3807.

$\overline{\text { Manuscript received: } 12.05 .2020}$ 